\title{
Traditional methods of harvesting termites used as poultry feed in Burkina Faso
}

\author{
Aïchatou Nadia Christelle Dao ${ }^{1}$ (D) - Fernand Sankara ${ }^{1}$. Salimata Pousga ${ }^{1} \cdot$ Kalifa Coulibaly ${ }^{1}$ • \\ Jacques Philippe Nacoulma ${ }^{1}$. Somalgré Ouedraogo ${ }^{1} \cdot$ Marc Kenis $^{2} \cdot$ Irénée Somda $^{1}$
}

Received: 14 May 2019 / Accepted: 15 October 2019/Published online: 3 December 2019

(C) The Author(s) 2019

\begin{abstract}
Termites are commonly used by smallholder farmers in West Africa to feed their poultry. A survey was carried out among poultry farmers in Burkina Faso to gather knowledge on the traditional methods used to obtain termites for poultry feed, to assess which termite genera are collected with which techniques and evaluate prospects for optimising and improving the collection and trapping methods. Data were collected among 1100 poultry farmers in eight regions of Burkina Faso on the harvesting techniques, the termite species and their local names as well as on the use of residues. After the interviews, termite samples were collected with the farmers and identified in the laboratory. At least five termite species were found. Species of the genera Odontotermes, Trinervitermes and Macrotermes are commonly given to chickens and guinea fowls whereas a Cubitermes species is sometimes used to feed guinea fowls. Two categories of methods are used to obtain termites, the direct collection by breaking termite mounds and the trapping of termites in containers filled with organic matters. The harvesting method varies with the termite genus, the region and the season. Different techniques with various types of containers and organic matters are used in the country and these techniques should be tested and compared to recommend the most efficient ones. The enhancement of termite trapping methods and their integration in poultry feed have the potential to significantly improve traditional poultry farming in Burkina Faso.
\end{abstract}

Keywords Indigenous knowledge $\cdot$ Termites $\cdot$ Insects as feed $\cdot$ Burkina Faso $\cdot$ Termite harvesting methods

\section{Introduction}

Insects are eaten, at least occasionally, by two billion people on earth (Van Huis et al. 2013; Meyer-Rochow and Chakravorty 2013). Termites are particularly nutritive and, in Africa, they are among the most consumed insects (Kinyuru et al. 2009; Lavalette 2013). They are also traditionally used to feed poultry in many West African countries such as Togo, Ghana, Benin and Burkina Faso, in particular in smallholder farming systems in which farmers hold a few scavenging chickens and guinea fowls (Hardouin 2003; Chrysostome et al. 2009; Diawara 2013; Sankara et al. 2018;

Aïchatou Nadia Christelle Dao christelledao@yahoo.fr

1 Institut du Développement Rural, Université Nazi Boni, 01, P.O. Box 1091, Bobo-Dioulasso, Burkina Faso

2 CABI, 1 Rue des Grillons, Delémont, Switzerland
Boafo et al. 2019). Farmers collect them either by breaking termite mounds or by trapping them using various methods (Kenis et al. 2014). However, harvesting termites becomes challenging when high quantities are needed to feed a larger flock or to increase the proportion of protein feed in the diet. The abundance of termites varies with seasons and regions and, in recent years, termite populations have decreased, forcing harvesters to walk increasingly long distances to collect the necessary amount to feed their poultry. Consequently many farmers stop feeding their poultry with termites, without finding alternative protein sources (Farina et al. 1991; Kenis et al. 2014; Sankara et al. 2018). Thus, the development of sustainable methods to collect, harvest and store termites is needed to ensure that traditional poultry farmers can provide protein feed to their birds without affecting the environment and local biodiversity (Dao 2016; Ouedraogo 2016; Boafo et al. 2019). In a recent study, Sankara et al. (2018) first assessed the use and knowledge of termites in poultry nutrition in Burkina Faso and analysed the factors influencing this use. Surveys showed that $78 \%$ of the farmers from Burkina 
Faso use termites to feed their poultry at least occasionally, but the practice is in decline and strongly varies among regions and provinces. Among the reasons for not using termites, the most common were the unavailability of termites followed by the lack of time and the lack of knowledge of trapping technique. This study complements that of Sankara et al. (2018) by describing and analysing the techniques traditionally used to collect and trap termites, assessing which termite genera are collected with which techniques and discussing prospects for optimising and improving the collection and trapping methods.

\section{Material and methods}

\section{Study area}

The study was carried out in eight of the 13 regions of Burkina Faso: Centre Ouest, Plateau Central, Nord, Est, Sahel, Centre Sud, Cascades and Hauts-Bassins (Fig. 1). These cover over $60 \%$ of the country and represent the three eco-climatic zones of Burkina Faso: These are, from North to South (Sankara et al. 2018):

(1) The Sahelian zone (regions Sahel and part of Nord), situated approximatively north of the $13^{\circ} 30^{\prime}$ parallel is defined as a zone experiencing 350-600 mm precipitations that are irregular and unevenly distributed over time and space. Temperatures often reach $40{ }^{\circ} \mathrm{C}$, especially in the hot dry season.

(2) The North Sudanian zone, or Sudano-sahelian zone (Centre Ouest, Plateau Central, Est and part of Nord and Centre Sud) is situated approximatively between the $11^{\circ} 30^{\prime}$ and $13^{\circ} 30^{\prime}$ parallel, where average annual precipitations vary between 600 and $900 \mathrm{~mm}$.

(3) The South Sudanian zone (Hauts Bassins, Cascades and part of Centre Sud) is situated approximatively south of the $11^{\circ} 30^{\prime}$ parallel. It receives from 900 to $1300 \mathrm{~mm}$ precipitations annually. This zone experiences milder temperatures.

Maps of the climatic zones and details of the vegetation and agricultural practices in the zones and regions are found in Dembele (2010). Further data on the climate of regions included in this study are found, e.g., in INSD ( 2014).

\section{Survey on the use of termites in poultry farming in Burkina Faso}

A total of 1100 poultry farmers in 32 villages in 25 provinces of the eight regions were selected. One hundred households
Fig. 1 Percentages of poultry farmers using the collection method, the trapping method, both methods and not collecting termites in the eight surveyed regions

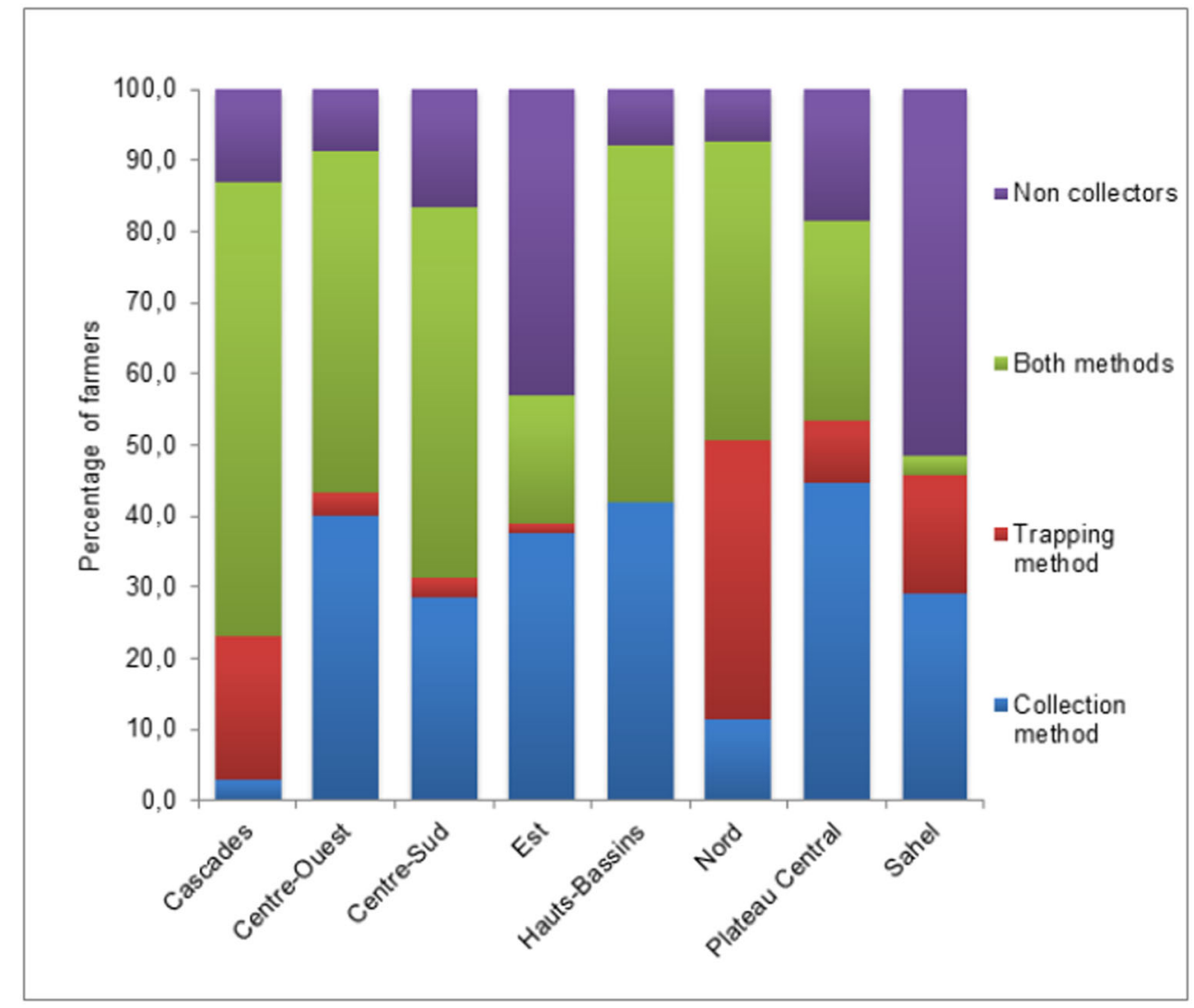


were chosen from one village in Haut-Bassins and Cascades whereas, in the six other regions, 30 farmers were selected in each of the five villages per region. The list of villages and provinces is listed in Sankara et al. (2018). The choice of provinces and villages was based on the number of inhabitants, the accessibility and the proportion of poultry farmers in the localities. Inside each province, the villages with the highest number of inhabitants were chosen (INSD 2008). But, to ensure geographic diversity in the samples, they were also selected on different roads. Farmers were randomly selected from lists provided by the Village Development Committees.

In the 1100 households, the farm manager was interviewed individually from 22 May 2015 to 16 July 2015. Direct, faceto-face interviews were conducted by two Master students who understand and speak the local languages of the different villages. The survey was made with a semi-structured questionnaire and was part of a large participatory research carried out in the framework of the project IFWA (see acknowledgements) that assessed the poultry farmers' perceptions for production and use of termites as poultry feed in Burkina Faso. Socio-demographic data of the surveyed farmers and their perception on the use of termites as poultry feed are described in Sankara et al. (2018). This paper specifically describes the answers that were given to the questions on the present practices to gather termites for poultry feed (Table 1). Interviews also included open questions and discussions, in particular on the management of residues of termite collection and trapping.

After each interview, farmers were asked to show the termites that they usually collect, either from termite mounds or from traps set up around the farm. When available, samples were collected and placed in $70 \%$ ethanol for identification in the laboratory. The identification to the genus or species level, were made using identification keys such as Bouillon and Mathot (1965, 1966), Sands (1965), Ruelle (1970) and Williams (1966). However, most West African termite species are difficult to identify (Korb et al. 2019) and, thus, in most cases, identifications were made only to genus level.

\section{Statistical analyses}

The data collected during the surveys were first entered into a Microsoft Office's Excel table and then transferred to the IBM SPSS 20 software environment. This software has been used to calculate the percentages of poultry farmers who do not collect termites, those who use collection method, those who use trapping method and those who use both methods by region. The frequencies of use of the container and substrate types were calculated and the Pearson's chi-square test was used for the comparison of percentages.

\section{Results}

\section{1- Collection methods}

Methods to collect termites can be classified into two categories: Direct collection of termites from their mounds and trapping of termites in containers. Direct collection implies the partial destruction of termite mounds. Techniques vary with

Table 1 Survey questionnaire on the use of termites by small poultry farmers in Burkina Faso

\begin{tabular}{|l|}
\hline Survey record $\mathrm{N}^{\circ}$ \\
\hline Investigator's name \\
\hline Region \\
\hline Contact details of enquired person \\
\hline Do you use termites in the poultry feed? Yes ( ) No ( ) \\
\hline If yes, which ones and what are their their vemacular names? \\
\hline How do you provide termites: \\
\hline Wild collection of termites mounds: ( ) \\
\hline Attraction and catching in container. ( ) \\
\hline $\begin{array}{l}\text { Which species of termites ( vernacular name or description) and describe the collecting methods of } \\
\text { the different species: }\end{array}$ \\
\hline Type of container and used substrates (also describe in detail the assembly scenario of containers): \\
\hline $\begin{array}{l}\text { Are there other types of termites in your village which you do not use in poultry farming? } \\
\text { Yes ( ) No ( ) }\end{array}$ \\
\hline If yes, which ones and why don't you use them \\
\hline
\end{tabular}


the termite genera. Small mounds of Trinervitermes and Cubitermes can be dug out with a hoe or a pickaxe. Mounds are collected in the morning between 6 am and 9 am because, later in the day when the sun is shining, termites go in the subterranean part of the nest. Mound pieces are placed in a bag or basket and termites are given to the fowls two or three times a day. According to the farmers, such type of termite collection is mostly practiced in the rainy season. Termites of the genus Macrotermes, which construct large mounds, are rather collected by making holes (usually about $50 \mathrm{~cm}$ deep) in the lateral part of the mound, and by inserting branches and leaves of various trees and bushes in the hole. Tree species include, among others, Guiera senegalensis J.F. Gmel., Diospyros mespiliformis Hochst. Ex A.DC., Piliostigma tonningii (Schumach.) Milne-Redh, Piliostigma reticulatum (DC.) Hochst. and Parinari curatellifolia Planch. Ex Benth. Three to four hours later, the branches and leaves, with termites on them, are removed, placed in containers and brought back to the farm.

In the trapping method, the first stage is to search for signs of termites such as mud sheeting and runways on the ground. These are usually found at sites with plant debris or dead animals, and can be spotted through the characteristic soils associated with termite tubes. Then, the soil is scraped with a hoe and a trap is placed of the soil. The trap consists of a container, overturned and filled with humid organic matter. The trap is placed in the morning (6-8 am) or in the evening (around $6 \mathrm{pm}$ ) and covered with foliage or pieces of fabric to protect it against the sun. Termites are collected in the following morning (6-7 am) or two days later. The organic matter, full of termites, is placed in another container and brought to the farm. If the pot is small and the quantity of organic matter is limited, the collection has to be made the following day otherwise termites will eat the whole content and leave the container. Larger containers can remain for two or more days. A variant of the method consists in placing the organic matter, e.g. cow dung, without container, on the termite nests and tubes, and collect the matter with termites by hand the following day. The trapping technique is used with termites of the genera Macrotermes and Odontotermes.

Both techniques are used in all investigated regions, but their respective use varies with regions (Pearson's chi-square = 59.060; $\mathrm{df}=7 ; P<0.001)$. The trapping technique is more practiced than the direct collection technique in the regions Nord $(81.3 \%$ of farmers said they trap termites at least occasionally) and Cascades (84.0\%). In the other regions, the direct collection is more commonly used. It is in the region Est that the trapping technique is practiced the least (19.4\%) (Fig. 1).

Discussions with farmers revealed that the pieces of termite mounds collected in the field for termites are recycled to build chicken runs, granaries or terraces in the farm year. Mixed with cow dung, they are also used to plaster walls to consolidate houses. Baits in the trapping containers, after the poultry has extracted termites, are thrown in the fields or in the vegetal garden as compost.

\section{2- Termite genera used as poultry feed in Burkina Faso}

In the survey, at least four termite genera were collected and cited as poultry feed, under various local names (Table 2):

- Trinervitermes species build small mounds (Fig. 2) and are used by poultry farmers to feed chickens, guinea fowls and turkeys. At least two undetermined species were found in samples collected with farmers.

- Odontotermes species (Fig. 3) build more often found in subterranean nests. Their presence is noticed by the damage they do to vegetal debris. They are given mainly to chicks. The specimens examined from farmers' traps could not be identified to the species level.

- Macrotermes species build large termite mounds (Fig. 4) and are used to feed chickens, guinea fowls and turkeys, mostly at the adult stage. Two species have been identified in the samples: M. bellicosus (Smeathman) and M. subhyalinus (Rambur).

Table 2 Names of termites in four local languages

\begin{tabular}{lllll}
\hline & \multicolumn{2}{l}{ Region of Centre-Ouest } & & Region of Hauts-Bassins \\
\cline { 2 - 3 } & Gourounsi (Lele) & Gourounsi (Nouni) & Bwaba & All regions \\
\hline Trinervitennes sp. & Tichou & Fiou & Banloo & Tembeko \\
& & & & Tembeto \\
Odontotermes sp. & Tchon & Fiou nonnon & Banloo & Mogodo \\
Macrotermes sp. & Tchoo & Fiou kiou & Too & Yaoré \\
Cubitermes sp. & Tichou N'djendjoulou & Fiou ipouè & Komidendembê & Tembek sablega \\
& & & & Tembek Pibri \\
\hline
\end{tabular}


Fig. 2 Mounds and soldier of Trinervitermes

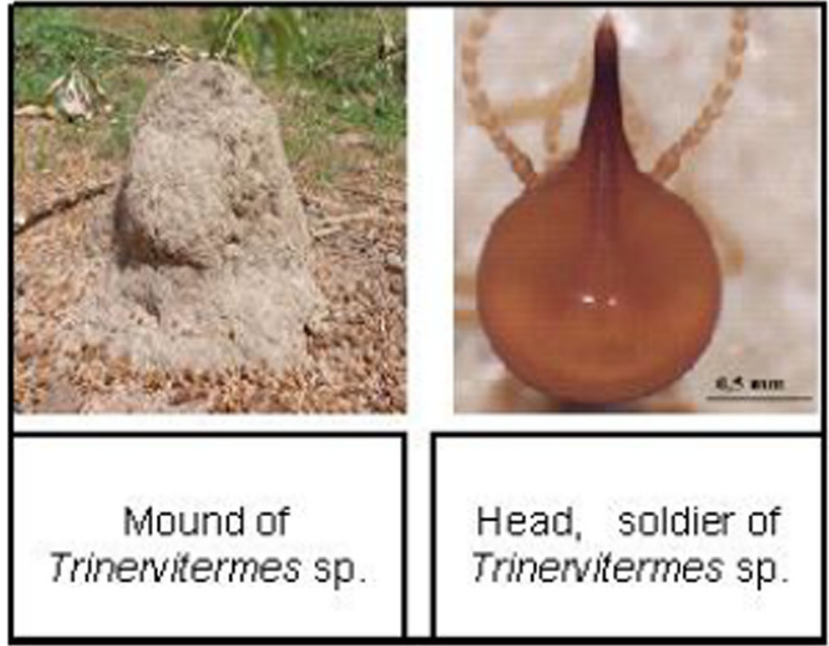

poultry feed. In the other regions, all four general were collected. In addition, samples collected with farmers also contained some Microtermes sp. and Coptotermes sp. but it was not clear whether these are used regularly as feed (Fig. 6).

\section{3- Baits and material used to trap termites}

The frequency of organic matter used as baits in the containers to trap termites vary with regions (Pearson's chi-square $=$

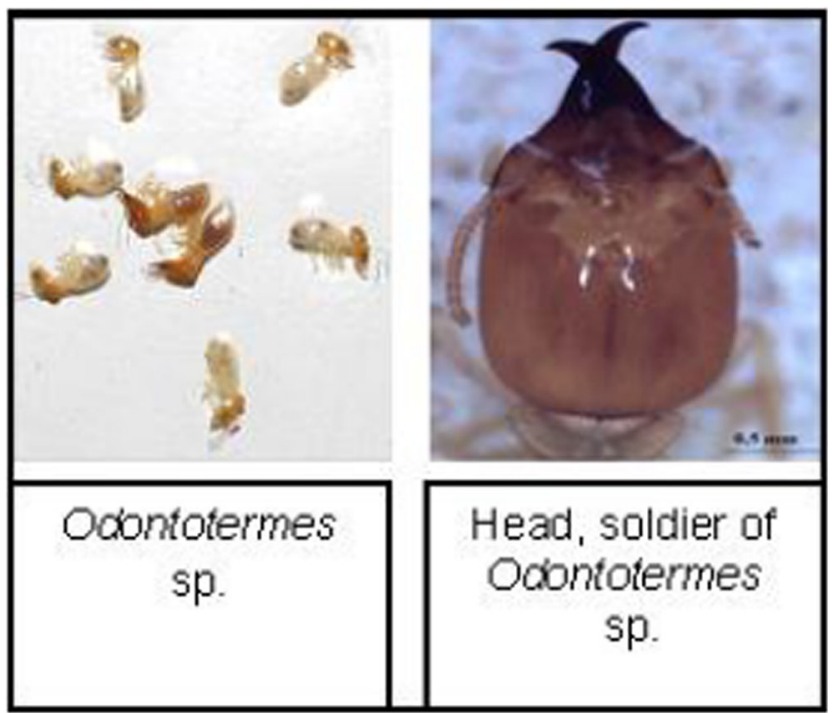

Fig. 3 Termites of the genus

Odontotermes
In the North and Sahel regions, only termites of the genera Odontotermes (Fig. 3) and Macrotermes (Fig. 4) used as

and at least one species is occasionally used for poultry feed. Some farmers said that they are given to guinea fowls but are toxic to chicken when given in high quantities. 
Fig. 4 Mounds and soldiers of Macrotermes spp.

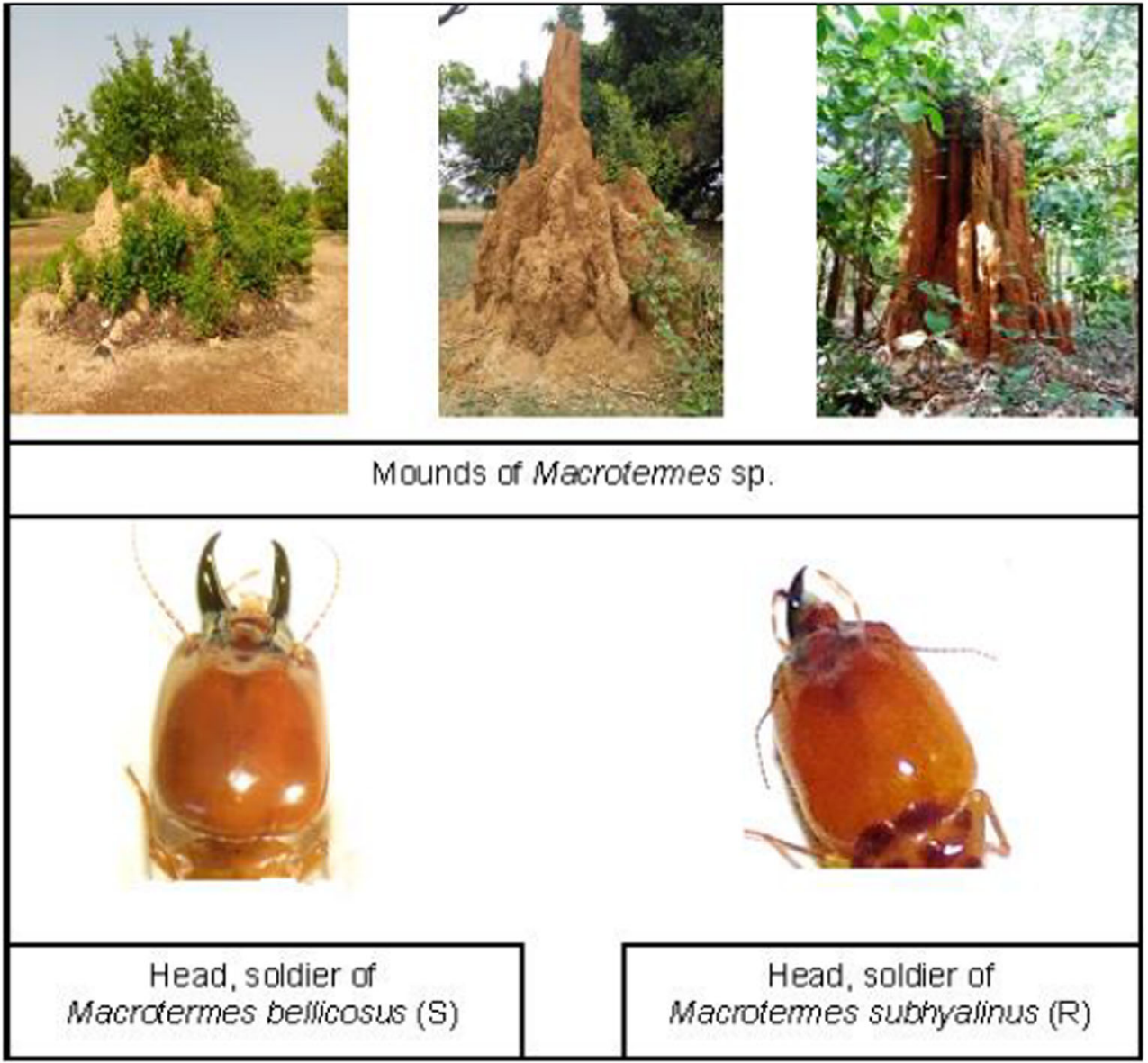

257.589; $\mathrm{df}=28 ; P<0,001)$. Baits that are used include: cow dung, mango stones, maize crop residues, other cereal crops and other plant debris (e.g. dead wood). Table 3 shows the frequency of utilisation of the baits in the different regions. Cow dung is more used than the other baits in most regions. Plant debris has been frequently cited in all regions and is a major bait in the Cascades and Est Regions. Mango stones are used mainly in Cascades, Centre Ouest and Nord, but not at all in some other regions. Maize residue is a major bait in HautsBassins.

Containers used in the trapping technique are mostly old containers that are not suitable for daily domestic uses. These are mainly calabashes, terra cotta pots (locally named « canaris »), metal boxes (empty cans of tomato, coffee, milk

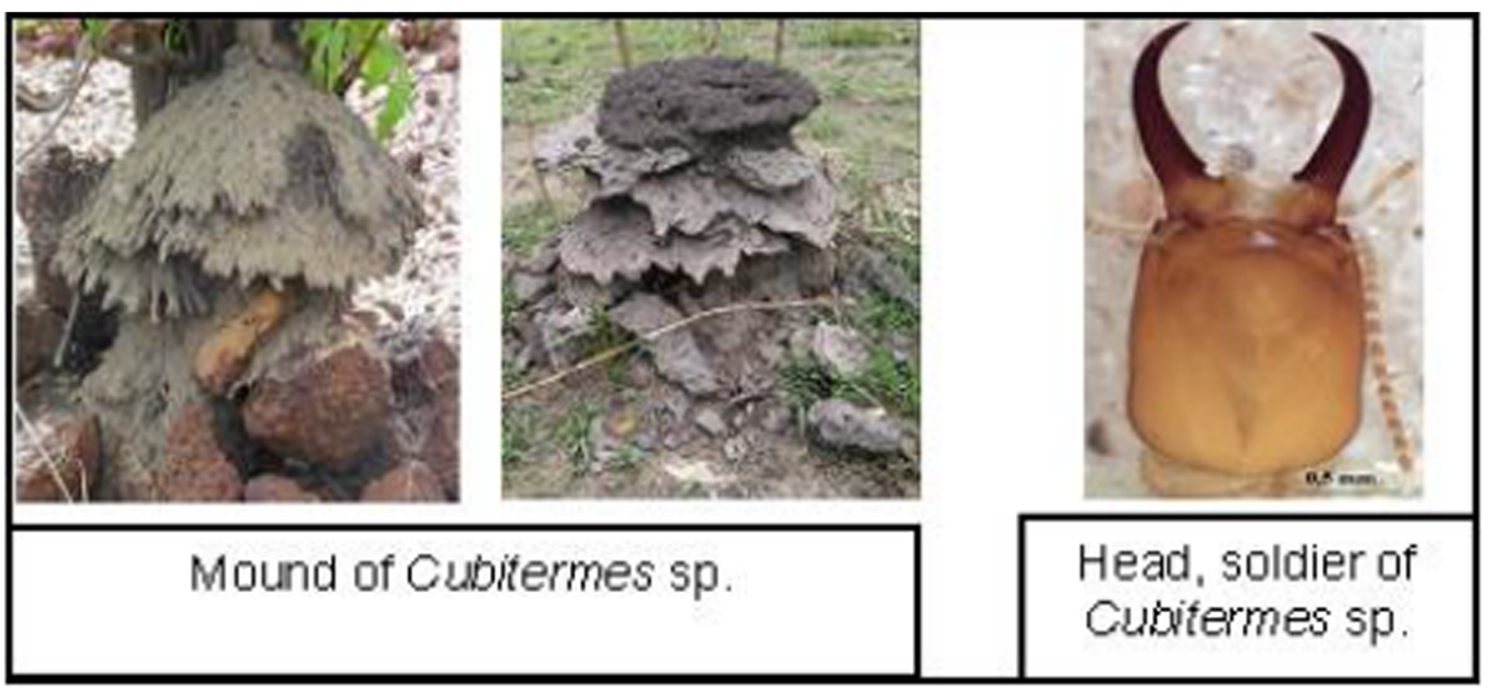

Fig. 5 Mounds and soldier of Cubitermes sp. 


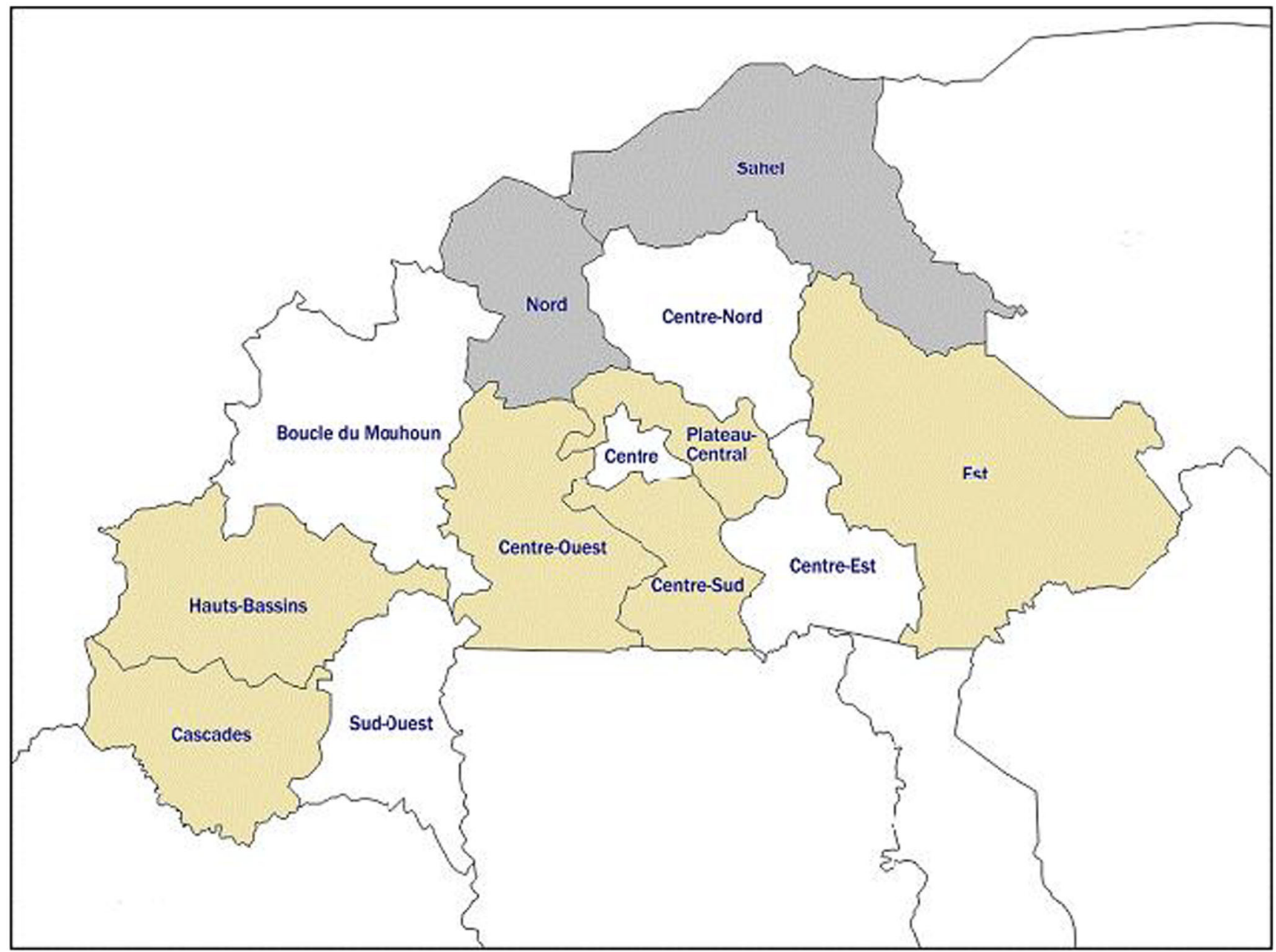

Fig. 6 Termite genera used as poultry feed per region in Burkina Faso.

Regions where Macrotermes and Odontotermes are collected, Regions where Macrotermes, Odontotermes, Cubitermes and Trinervitermes are collected, Regions not surveyed

powder, etc.) and plastic containers (e.g. cut plastic barrels or gas tanks) (Table 4). The frequency of containers' types varies with regions (Pearson's chi-square $=398.915$; $\mathrm{df}=28$;
$P<0,001)$. Canaris are used everywhere but metal boxes are more commonly used in Centre Ouest and Plateau Central. Calabashes and plastic containers are not much used. In

Table 3 Frequency of organic matters used in the containers to trap termites in the different regions, expressed as percentage of all citations. Most farmers have cited several organic matters

\begin{tabular}{|c|c|c|c|c|c|c|c|}
\hline Regions & $\begin{array}{l}\text { Cow dung } \\
\%\end{array}$ & $\begin{array}{l}\text { Plant debris } \\
\%\end{array}$ & $\begin{array}{l}\text { Mango stones } \\
\%\end{array}$ & $\begin{array}{l}\text { Residues of } \\
\text { other cereals } \\
\%\end{array}$ & $\begin{array}{l}\text { Residue of } \\
\text { maize crop } \\
\%\end{array}$ & $\begin{array}{l}\text { Nomber of farmers } \\
\text { trapping termites }\end{array}$ & $\begin{array}{l}\text { Nomber of substrates' } \\
\text { citations }\end{array}$ \\
\hline Cascades & $30,7 \mathrm{a}$ & $32,6 a$ & $21,8 \mathrm{ab}$ & $1,1 \mathrm{c}$ & $13,8 b$ & 85 & 261 \\
\hline Centre Ouest & $48,4 \mathrm{a}$ & $23,2 \mathrm{ab}$ & $19,4 b$ & $3,2 \mathrm{c}$ & $5,8 \mathrm{c}$ & 77 & 155 \\
\hline Centre Sud & $48,0 \mathrm{a}$ & $11,7 d$ & $7,6 \mathrm{~d}$ & $14,6 \mathrm{c}$ & $18,1 \mathrm{~b}$ & 82 & 171 \\
\hline Est & $54,3 \mathrm{a}$ & $41,3 \mathrm{a}$ & $0,0 \mathrm{~b}$ & $0,0 \mathrm{~b}$ & $4,3 b$ & 29 & 46 \\
\hline Hauls-Bassins & $47,1 \mathrm{a}$ & $9,8 \mathrm{c}$ & $2,0 \mathrm{c}$ & $2,0 \mathrm{c}$ & $39,2 b$ & 50 & 102 \\
\hline Nord & $48,1 \mathrm{a}$ & $26,6 b$ & $16,9 b$ & $4,2 \mathrm{c}$ & $4,2 \mathrm{c}$ & 122 & 237 \\
\hline Plateau Central & $76,8 \mathrm{a}$ & $7,2 \mathrm{~b}$ & $0,0 \mathrm{~b}$ & $5,8 \mathrm{~b}$ & $10,1 b$ & 55 & 69 \\
\hline Sahel & $60,0 \mathrm{a}$ & $22,5 b$ & $2,5 \mathrm{c}$ & $2,5 \mathrm{c}$ & $12,5 b$ & 29 & 40 \\
\hline
\end{tabular}

Values in the same line followed by the same letters and not significantly different at 0.05 level 
Table 4 Frequency of containers' types used for trapping termites in the different regions, expressed as percentage of all citations. Some farmers have cited several containers' types

\begin{tabular}{llllllll}
\hline Regions & Calabash & Terra cotta pot & Metal box & Plastic container & No container & $\begin{array}{l}\text { Nomber of farmers } \\
\text { trapping termites }\end{array}$ & $\begin{array}{l}\text { Nomber of containers' } \\
\text { citations }\end{array}$ \\
\hline Cascades & $0 \mathrm{~b}$ & $97,6 \mathrm{a}$ & $0 \mathrm{~b}$ & $2,4 \mathrm{~b}$ & $0 \mathrm{~b}$ & 85 & 85 \\
Centre Ouest & $3,8 \mathrm{c}$ & $35,4 \mathrm{~b}$ & $57,0 \mathrm{a}$ & $0 \mathrm{c}$ & $3,8 \mathrm{c}$ & 77 & 79 \\
Centre Sud & $0 \mathrm{c}$ & $55,6 \mathrm{a}$ & $34,7 \mathrm{a}$ & $9,7 \mathrm{~b}$ & $0 \mathrm{c}$ & 82 & 124 \\
Est & $0 \mathrm{c}$ & $43,8 \mathrm{~b}$ & $0 \mathrm{c}$ & $9,4 \mathrm{c}$ & $46,9 \mathrm{a}$ & 29 & 32 \\
Hauts-Bassins & $0 \mathrm{~b}$ & $100 \mathrm{a}$ & $0 \mathrm{~b}$ & $0 \mathrm{~b}$ & $0 \mathrm{~b}$ & 50 & 50 \\
Nord & $2,4 \mathrm{c}$ & $64,8 \mathrm{a}$ & $25,6 \mathrm{~b}$ & $0 \mathrm{c}$ & $7,2 \mathrm{c}$ & 122 & 125 \\
Plateau Central & $5,6 \mathrm{c}$ & $11,1 \mathrm{~b}$ & $77,8 \mathrm{a}$ & $1,9 \mathrm{c}$ & $3,7 \mathrm{c}$ & 55 & 57 \\
Sahel & $0 \mathrm{c}$ & $22,6 \mathrm{~b}$ & $12,9 \mathrm{c}$ & $16,1 \mathrm{c}$ & $48,4 \mathrm{a}$ & 29 & 31 \\
\hline
\end{tabular}

Values in the same line followed by the same letters and not significantly different at 0.05 level

Sahel and Est Regions, about half of the farmers said that they do not use containers and directly apply the baits, mostly cow dung, on termite nests and tubes. This technique is not much used in the other regions (Table 4).

\section{Discussion}

\section{Collection methods}

This survey showed that two categories of methods are abundantly used to collect termites in all investigated regions, the direct collection from termite mounds and the trapping of termites in containers. The same categories of method have recently been described from Ghana as well (Boafo et al. 2019). Direct collection is easy but has two drawbacks. Firstly, termite mounds are not always easily available and collectors, often children, sometimes have to walk very far to collect termites (Kenis et al. 2014). Secondly, these methods are not sustainable because they may destroy the termite nests, which play an important role in the functioning of African soil ecosystems. Even when the colony is not directly destroyed, digging holes favours the attack of predators such as ants. Hardouin (2003) had noticed this issue and therefore suggested to favour the trapping methods, which had already been described by Farina et al. (1991), Chrysostome (1997) and others. At first view, the trapping method is more difficult to implement because it requires material and time for preparation of the traps. However, traps can be placed around the farm without destroying the nests and even inconspicuous nests that are identified by mud tubes and holes in the soil are suitable. This method could be improved by finding the best technique, including the most efficient organic matters, the best containers and the most appropriate timing and sites for exposing the traps.

\section{Termite genera}

Four termite genera are commonly used, Trinervitermes and Cubitermes, which are obtained through direct collection, Odontotermes, which is trapped with containers, and Macrotermes, which can be collected using both methods. All termites can be collected throughout the year but Trinervitermes and Cubitermes are more commonly collected in the rainy season, possibly because the mounds are more easily destroyed in that season. In contrast, Odontotermes and Macrotermes are more commonly trapped with containers in the dry season because, in the rainy season, according to farmers, termite tubes are regularly washed out by the rain and Odontotermes nests are less conspicuous. The climate may also explain why Odontotermes and Macrotermes are collected throughout the country whereas Trinervitemes and Cubitermes mounds are not harvested in the Sahelian zone (North and Sahel regions), which is the driest area of the country. However, it may also simply be that Trinervitermes and Cubitermes are less abundant in these regions. Kifukieto et al. (2014) showed that termites' distribution, diversity and abundance vary with climate but also with soil and vegetation types.

While no producer has expressed limitations in the use of Odontotermes spp., which can be given at libidum for chicks, some issues have been raised regarding the three other genera. Macrotermes spp. cannot be given to chicks of less than 24 weeks because soldiers can hurt and even kill chicks by biting their throat. Some farmers said that a species of Trinervitermes is toxic and only experienced farmers can recognize them, which hampers their use. Trinervitermes spp. are toxic through their soldiers that spit toxins (diterpenes and monoterpenes) with their snout and it is possible that the "toxic species" may be species or nests with high proportions of soldiers, or soldiers that produce more toxic substances than others. Cubitermes sp. can be used without danger for guinea 
fowls and keets but, in large quantities may be toxic to chicken. While the reasons for the toxicity of species of the genera Trinervitermes and Cubitermes should be further investigated, other authors have mentioned similar issues. For example, in Benin, Chrysostome (1997) reported that a species of the genus Noditermes is known for being toxic to poultry, which was confirmed in feeding tests.

In Ghana, Boafo et al. (2019) also mentioned that soldiers of Trinervitermes and Macrotermes as well as some Cubitermes and Amitermes species are known to be poisonous or damaging to chicks and provide symptoms for the different termite species. Other termites are reported as poultry feed in Africa and elsewhere. In their review, Figueirêdo et al. (2015) reported over 40 species used as food or feed worldwide. Before the recent studies of Boafo et al. (2019), Sankara et al. (2018) and this study in Ghana and Burkina Faso, hardly anything was known about the use of species of the genera Odontotermes, Trinervitermes and Cubitermes in feed or food. In contrast, $M$. bellicosus and M. subhyalinus have been particularly well studied in Africa. They are consumed also by humans in many countries. They are very rich in nutrients, i.e. proteins, vitamins and minerals, and their consumption has been encouraged (Ntukuyoh et al. 2012). Furthermore, their large size allows them to be preserved dry. Sogbesan and Ugwumba (2008) tested M. suhyalinus in catfish feed and suggest that it is easier and more profitable to preserve and give them dry than fresh. In Congo, Munyuli and Balezi (2002) showed that dry termites can successfully replace the expensive meet meal commonly used in poultry feed diets.

\section{Baits and material used to trap termites}

Various types or containers and contents are used across Burkina Faso to trap termites. The containers are usually old or broken pots and the baits are animal or plant wastes so that this technique does not cost anything to implement. Baits used to trap termites may reflect their local abundance. For example, mango stones are used in the Cascades region, where mango trees are particularly abundant. Cow dung is abundant everywhere and it is the easiest and most commonly used bait to attract termites. In some regions, cow dung is simply placed on the ground. In most cases, however, a container is used, which can be of various sizes and material. Containers need to keep the organic matter at the right humidity and at low temperature, which may be the reason why terra cotta pots are abundantly used, in contrast to plastic containers that tend to heat their content. In a similar survey in Ghana, farmers also advised the use of earthenware as it remains cooler than containers made of other materials (Boafo et al. 2019). They also stated that, to maintain good microclimate for the termites, baited containers can be covered with leaves after placing on termite mounds.

\section{Conclusion}

This study allowed us to highlight and describe traditional activities related to the use of termites as poultry feed in rural communities in Burkina Faso. Termites are frequently given to poultry and represent an important source of proteins in traditional poultry farming. In addition, residues of termite mounds and traps are used in construction work and as compost, respectively. While the direct collection through destruction of termite mounds is not sustainable and cannot be recommended, the trapping system with containers and organic matters should be encouraged in villages that are not practicing it. However, more research is needed to improve the trapping and use of termites in poultry feed. Tests should be conducted to assess which containers, baits and techniques of trap exposure are most efficient. Techniques are likely to be different for the different species, which should be all identified to the species level. The effect of intense trapping around farms on termite populations should be studied. Finally, if methods are found to trap termites in high quantity in a sustainable way, the possibility of drying termites and integrating termite meal in poultry diets should be considered.

Acknowledgements We thank all poultry farmers that took time to respond to the survey and all agents from the ministry of animal resources for their support during the survey. This study was carried out as part of the project IFWA - Sustainable use of insects to improve livestock production and food security in smallholder farms in West Africa, funded by the Swiss Agency for Development and Cooperation and the Swiss National Science Foundation, in the framework of the Swiss Programme for Research on Global Issues for Development (R4D). Marc Kenis was partly funded though the CABI Development Fund (supported by contributions from the Australian Centre for International Agricultural Research, the UK's Department for International Development, and others).

\section{Compliance with ethical standards}

Conflict of interest The authors declare that they have no conflict of interest.

Open Access This article is distributed under the terms of the Creative Commons Attribution 4.0 International License (http:// creativecommons.org/licenses/by/4.0/), which permits unrestricted use, distribution, and reproduction in any medium, provided you give appropriate credit to the original author(s) and the source, provide a link to the Creative Commons license, and indicate if changes were made.

\section{References}

(INSD) Institut National de la Statistique et de la Démographie (2008) Recensement Général de la Population et de l'Habitation de 2006: Résultats définitifs. INSD, Ministère de l'Economie et des Finances, Burkina Faso

(INSD) Institut National de la Statistique et de la Démographie (2014) Annuaire statistique 2013. INSD, Burkina Faso 
Boafo HA, Affedzie-Obresi S, Gbemavo DSJC, Clottey VA, Nkegbe E, Adu-Aboagye G, Kenis M (2019) Use of termites by farmers as poultry feed in Ghana. Insects 10(69):1-13

Bouillon A, Mathot G (1965) Quel est ce termite Africain? Zooleo $\mathrm{N}^{\circ} 1$, Kinshasa, RDC

Bouillon A, Mathot G (1966) Quel est ce termite Africain? Zooleo $N^{\circ} 1$, Supplément, Kinshasa, RDC

Chrysostome C.A.A.M (1997) Utilisation des termites pour le démarrage des pintadeaux; essai d'alimentation en milieu réel pp. 117-124. In : Proceedings Atelier RADAR, 9-13 December 1997, M'Bour, Sénégal.

Chrysostome CAAM, Coubéou PT, Dakpogan H, Mensah GA (2009) Comment collecter des termites avec des noix de rônier pour l'alimentation des pintadeaux? pp. 5-12. In : Référentiel Technicoéconomique Pour la Production Avicole. Fiche technicoéconomique de la CASPA. Ministère des Affaires Etrangères du Danemark et Ministère de l'Agriculture, de l'Elevage et de la Pêche du Bénin, Cotonou, Benin. Volume 1

Dao ANC (2016) Inventaire et optimisation des techniques de collecte et de production de termites dans trois régions du Burkina Faso : Centre Ouest, Plateau Central et Nord. Mémoire du Diplôme d'Ingénieur du Développement Rural. Université Polytechnique de Bobo-Dioulasso, Burkina Faso

Dembele Y (2010) Cartographie des zones socio-rurales du Burkina Faso. Un Outil d'aide à la Planification pour la Gestion de l'Eau en Agriculture : Food and Agriculture Organisation, Rome, Italy

Diawara M (2013) Impact de l'utilisation des termites en aviculture traditionnelle au Burkina Faso. Mémoire du Diplôme d'Ingénieur du Développement Rural. Université Polytechnique de BoboDioulasso, Burkina Faso

Farina L, Demey F, Hardouin J (1991) Production de termites pour l'aviculture villageoise au Togo. Tropicultura 9(4):181-187

Figueirêdo FREC, Vasconcellos A, Policarpo IS, Nóbrega RRA (2015) Edible and medicinal termites: a global overview. J Ethnobiol Ethnomed 11:1-7

Hardouin J (2003) Production d'insectes à des fins économiques ou alimentaires : mini-élevage et Bureau for Exchange and Distribution of information on Minilivestock (BEDIM). Notes fauniques de Gembloux 50:15-25

Kenis M, Koné N, Chrysostome CAAM, Devic E, Koko GKD, Clottey VA, Nacambo S, Mensah GA (2014) Insects used for animal feed in West Africa. Entomologia 2:107-114

Kifukieto C, Deligne J, Kachaka C, Francis F (2014) Inventaire préliminaire des termites (Isoptera) du plateau des Batékés en République Démocratique du Congo. Entomologie Faunistique 67: 49-57

Kinyuru JN, Kenji GM, Njoroge MS (2009) Process development, nutrition and sensory qualities of wheat buns enriched with edible termites (Macrotermes subhyalinus) from Lake Victoria region, Kenya. AJFAND 9:1739-1750

Korb J, Kasseney BD, Cakpo YT, Daza RHC, Gbenyedji JNKB, Ilboudo ME, Josens G, Koné NA, Meusemann K, Ndiaye AB, Okweche SI, Poulsen M, Roisin Y, Sankara F (2019) Termite taxonomy, challenges and prospects: West Africa, a case example. Insects 10,32 : $1-8$

Lavalette M (2013) Les insectes : une nouvelle ressource en protéines pour l'alimentation humaine. Docteur en Pharmacie, Université de Lorraine, France

Meyer-Rochow VB, Chakravorty J (2013) Notes on entomophagy and entomotherapy generally and information on the situation in India in particular. Appl Entomol Zool 48:105-112

Munyuli TBM, Balezi N (2002) Utilisation des blattes et des termites comme substituts potentiels de la farine de viande dans l'alimentation des poulets de chair au Sud-Kivu, République Démocratique du Congo. Tropicultura 20:10-16

Ntukuyoh AI, Udiong DS, Ikpe E, Akpakpan AE (2012) Evaluation of nutritional value of termites (Macrotermes bellicosus): soldiers, workers, and queen in the Niger Delta region of Nigeria. Int $\mathbf{J}$ Food Nutri Saf 1:60-65

Ouedraogo S (2016) Contribution à l'étude sur l'utilisation des termites (Macrotermes $s p$ ) en aviculture traditionnelle au Burkina Faso. Mémoire du Diplôme d'Ingénieur du Développement Rural. Université Polytechnique de Bobo-Dioulasso, Burkina Faso

Ruelle J-B (1970) A revision of the termites of the genus Macrotermes from the Ethiopian region (Isoptera : Teritidae). Bull Br Mus Nat Hist 24:365-444

Sands WA (1965) Revision of the termite subfamily Nasutitermitinae (Isoptera, Termitidae) from the Ethiopian region. Bull Br Mus Nat Hist 4:1-129

Sankara F, Pousga S, Dao NCA, Gbemavo DSJC, Clottey VA, Coulibaly K, Nacoulma JP, Ouedraogo S, Kenis M (2018) Indigenous knowledge and potential use of termites as poultry feed in Burkina Faso. $\mathrm{J}$ Insects Food Feed 4:211-218

Sogbesan AO, Ugwumba AAA (2008) Nutritional evaluation of termite (macrotermes subhyalinus) meal as animal protein supplements in the diets of heterobranchus longifilis (Valenciennes, 1840) fingerlings. Turk J Fish Aquat Sci 8:149-157

Van Huis A, Van Itterbeck J, Klunder H, Mertens E, Halloran A, Muir G, Vantomme P (2013) Edible insects : future prospects for food and feed security. Food and agriculture Organization of the United Nations (FAO). For Paper 171:1-187

Williams RMC (1966) The east African termites of the genus Cubitermes (Isoptera: Termitidae). Trans R Entomol Soc Lond 118:73-118

Publisher's note Springer Nature remains neutral with regard to jurisdictional claims in published maps and institutional affiliations. 